\title{
Assessment of Fluvial Channel Dynamics of Padma River in Northwestern Bangladesh
}

\author{
Abu Reza Md. Towfiqul Islam ${ }^{1,2}$ \\ ${ }^{1}$ College of Atmospheric Sciences, Nanjing University of Information Science and Technology, China \\ ${ }^{2}$ Department of Disaster Management, Begum Rokeya University, Bangladesh
}

Copyright $(2016$ by authors, all rights reserved. Authors agree that this article remains permanently open access under the terms of the Creative Commons Attribution License 4.0 International License

\begin{abstract}
Fluvial channel form and its dynamics over the period of time have been a major interest of study in fluvial geomorphology. The present study deals with the fluvial morphological characteristics of the Padma River in northwestern Bangladesh. Morphological and morpho-dynamic maps of the Padma River were prepared using remote sensing techniques. Sinuosity ratio, braided index and island percentage of the study area were estimated for the year of 1977, 1989 and 2000 respectively. Results showed a remarkable change in position of bank and channel as well as bars along with their geometry and morphology over time. Result also demonstrates that the bank line is unstable and migrated continuously towards westward in the recent decades. In addition, the study reveals that overall width of the Padma River is varied significantly during the last 23 years. Different maps and Landsat images (band 4) depict that the river shifting is abnormal which is alarming for the existence of the study area people. Outcomes of this study obtained from investigating satellite remote sensing imagery provide valuable information about the bank erosion and channel shifting of fluvial morphology of the Padma River and to recommend some protective measures.
\end{abstract}

Keywords Fluvial Morphology, Satellite Remote Sensing, Northwestern Bangladesh, Landsat Images and Channel Shifting

\section{Introduction}

Bangladesh has a unique hydro-geologic setting and deltaic floodplains which are formed by the deposition of the Ganges (Padma), Brahmaputra (Jamuna) and Meghna River [1]. These river formations and its dynamics over time have been an interesting subject of study in geomorphology [2]. Bangladesh is intersected by more than 600 rivers, which makes this country's fertile land [14]. Among them, the Padma, the Megna, the Jamuna are the big and wide rivers of Bangladesh. These three major rivers, their distributaries that control its hydrological and fluvio-morphological behaviors. In addition, river differs from one another in their physical features and channel dynamics. The Padma River plays an important role in changing morphological behaviors than any other rivers [3]. However, the Padma River along its course in northwestern Bangladesh is vulnerable to channel shifting and bank erosion [4]. Since prehistoric time, the Padma River is known as 'Sharbagrashi' (literally in English word 'disastrous') due to its intense channel shifting and destructive bank erosion [5]. Hence, channel morphology of the Padma River forms a complex interaction of channel dynamics and sediment characteristics in the study area.

Satellite remote sensing technique is very effective in examining fluvial channels dynamics over a large area. Although this technique has been widely used to examine fluvial channel migration [6-7] and to identify palaeo-braided channels on terrace surfaces [8] and also to investigate the long-term trends and rates of bank erosion and accretion of the Jamuna River [9]. A number of studies have investigated basic channel change by using geospatial techniques, such as overlaying a series of historical channel maps [10-12] in different types of river systems. Moreover, the Geological Survey of Bangladesh (GSB) has sporadically carried out geological and geomorphological study of the Padma River. Remote sensing data are applied to monitor the river channel shifting, anthropogenic changes and land use pattern related activities in Bangladesh [13-15]. Takagi et al. [16] assessed the channel braiding and stability of the Jamuna River in Bangladesh part using remote sensing data from late 1960s to late 1990s. Mount et al. [17] showed that the continuous wavelet transforms were used to explore spatiotemporal patterns of multi-scale bank line retreat along a $204 \mathrm{~km}$ reach of the Jamuna River in Bangladesh.

Recently, several studies have been focused on morpho-dynamics of the Ganges-Brahmaputra Jamuna Rivers of Bangladesh. For instance, Akter et al. [18] examined the braiding process and river bank erosion of the Jamuna River in Bangladesh. Sarker et al. [19] studied the 
morpho-dynamics of the Brahmaputra-Jamuna River in Bangladesh. Furthermore, Bhuiyan et al. [20] investigated the morphological changes of the lower Brahmaputra-Jamuna River (BJR) in Bangladesh by using both remote sensing technique and GIS environment. Unfortunately, there are few studies concerning the channel shifting and fluvial systems of the Padma River in Bangladesh [21-23]. For planning and sustainable development of Bangladesh, identification of fluvial channel morphology of a river like the mighty Padma River is essential. Therefore, this paper aims to assess the changes of fluvial morphology and channel dynamic of the Padma River and to recommend some protective measures for future in the study area.

\section{Methodology}

\subsection{Study Area}

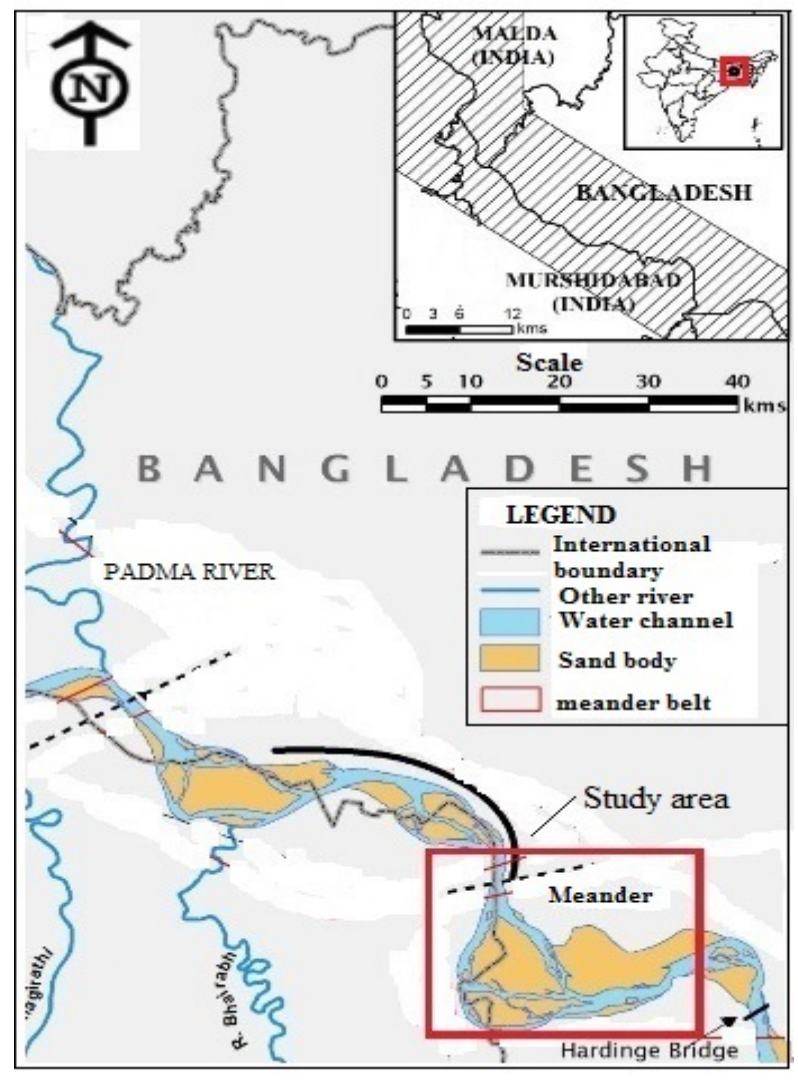

Figure 1. Location map shows the study area (After modified [34])

The study area in northwestern Bangladesh which is located in the channel-bar complex along the bank of the Padma River near Charghat and Bagha Upazila of Rajshahi district and Pakshi upazilla of Pabna district, Bangladesh. The study area lies within the longitude $88^{\circ} 45^{\prime}$ to $89^{\circ} 0^{\prime} \mathrm{E}$ and latitude $24^{\circ} 4^{\prime}$ to $24^{\circ} 12^{\prime} \mathrm{N}$ which covers about $45 \mathrm{~km}$ length of the Padma River (Fig. 1). The Padma River has a mean flow of around $30,000 \mathrm{~m}^{3} / \mathrm{s}$, bankfull flow about $76,000 \mathrm{~m}^{3} / \mathrm{s}$ and transport roughly $1 \times 10^{9} \mathrm{t} /$ year of sediment, making it one of the largest river in the world [24]. Physiographically, the study area occupies in the Ganges River Floodplain. Geologically, the area is situated on the north-northwestern part of the Bengal Basin [25].

\subsection{Data and Methods}

Fluvial channel morphology was investigated by the satellite remote sensing data. Occasionally, satellite images make poor resolution to evaluate fluvial channel morphology of river systems. For that reason, by integrating satellite image and field data may provide better option for understanding the river morpho-dynamics. The data used in the study were collected during the dry season from Geological Survey of Bangladesh (GSB) and the Centre for Environmental and Geographical Information Services (CEGIS), Dhaka. Moreover, data would be more likely to attain cloud free condition of Landsat images during the dry season and other ground conditions were relatively consistent from year to year. Base map of scale 1:50000 (2001) was obtained from Local Government Engineering Department (LGED), toposheet with scale 1:50,000 (1968) was also sourced from Bangladesh survey. The behavior of major channel patterns of the river was analyzed from 1977 to 2000. Satellite imagery of Landsat MSS (1977) and TM (1989) and ETM+ (2000) bands of 3 different years were used in this study (Table 1).

Three satellite images were mosaiced and geo-referenced to topographic sheet and base map (scale 1:50,000) and projected using the UTM (Universal Transverse Mercator)-46 N projection [26]. The study focused on the geomorphological units and river bank erosion based on the satellite image data. These data were employed for identifying the morphological changes of the Padma River. The base map, topo map and satellite Landsat images of MSS 1977, TM 1989, ETM+2000 were generated to use for a relative analysis of sinuosity ratio, braided indexed and island area percentage of total study area. The satellite imagery results were evaluated to define the relations between river bank line and bar growth. ArcGIS (9.2 versions) and Adobe illustrator (CS 11) graphical software were used for image processing and interpretation.

Table 1. Satellite images used in the present study

\begin{tabular}{|c|c|c|c|}
\hline Year & $\begin{array}{c}\text { Date of } \\
\text { acquisition }\end{array}$ & Types of images & $\begin{array}{c}\text { Resolution } \\
(\mathrm{m})\end{array}$ \\
\hline 1977 & 09 February & Landsat MSS (Band 4) & 80 \\
\hline 1989 & 11 November & Landsat TM (Band 4) & 30 \\
\hline 2000 & 17 November & Landsat ETM+ (Band 4) & 30 \\
\hline
\end{tabular}

In image processing stage, geometric corrections were conducted to rectify the images into UTM-46 N projection system [26]. Three images were converted into a base map of LGED in order to register digital data for geo-referencing purposes. Geomorphic map was prepared from each digitally classified image showing river channels, sand bars and river bank lines etc. 
Remote sensing data reduce spatial sampling problems of bank line erosion which enable to monitor the minimal contact on the bank face itself [27]. Moreover, among the available methods erosion length within the reaches in this study was identified based on the exhibited bank line shifts in the duration of total study area [18]. Finally, a spatial superimposition of bank line of each classified images between three years were carried out by using the GIS modeling techniques to generate a map showing the changes detection of fluvial channel dynamics.

The following formula is applied to compute the sinuosity ratio (SR) in the present study

$$
\mathrm{SR}=\frac{\mathrm{Sl}}{\mathrm{Cl}}
$$

where, SR is the sinuosity ratio, $\mathrm{Sl}$ is the stream length (m) and $\mathrm{Cl}$ is the channel length (m)

The braiding index is defined by the following equation

$$
\mathrm{BI}=2 \sum \frac{\mathrm{Li}}{\mathrm{Lr}}
$$

where $\mathrm{BI}$ is the braided index, $\mathrm{Li}$ is the total length of bars/islands in the reach $(\mathrm{m})$ and $\mathrm{Lr}$ is the length of reach measured midway distance between the banks (m).

\subsection{Geomorphological Units}

Geomorphological units consist of recent alluvium plain in the study area. Geomorphological features of the Padma River differ from one place to another in the northwestern Bangladesh. It is recognized on the basis of the satellite image characteristics (e.g. tonal variation, texture, size, shape) and fluvial features [28]. Geomorphological units are identified by different erosion processes [29]. Remote sensing data are effective to map geomorphological units [30].

\subsubsection{Active Channel}

Active channel is perpetual water flow in all over the year. This unit is the main feature of the study area (Fig. 2).

\subsubsection{Mid channel bar}

This channel bar is ephemeral in nature and position of the bar within the channel is likely to be changed with each sizeable flood. The channel bar is located within the active channel which is exposed during the late winter and summer seasons. This bar consists of course to medium grained sand (Fig. 2).

\subsubsection{Lateral bar deposit}

Lateral bar is connected to the main floodplain deposit. This bar is longitudinal, elongated and transverse to the stream alignment which is exposed only during the winter and summer period (Fig. 2).

\subsubsection{Old bar deposit}

The old bar is the main geomorphological units within the channel area. This bar contains several cycles of sedimentation that forms multistoried changing sequences [31]. This bar identifies by its geomorphic forms and light tone (Fig. 2).

\subsubsection{New bar deposit}

New bar is small scale bar within the channel floors, which is characterized by sand waves without any vegetation covers. This bar consists of loose, light gray to white and medium to fine-grained sands. The new bar is comparatively lower than that of the older bar. In satellite images, it identifies by light tone (Fig. 2).

\subsubsection{Abandoned channel deposit}

The unit is extended thin depressions and narrow discontinuous water courses with or without water throughout the year. It consists of silty clay, lies beneath by silty sand to fine sand deposits. Vegetation forms elongated shape like geometry (Fig. 2).

\subsubsection{Floodplain deposit}

Flood plain deposit is located between natural levee and flood basin and its elevation is lower than natural levee [32]. This unit is very gently sloping towards the flood basin. Flood plain deposit consists of silty clay to organic rich gray clay and partly decomposed of grass roots [33]. The study area has converted to the cultivated lands which exhibits table like geometric shape on either sides of the Padma River (Fig. 2). 


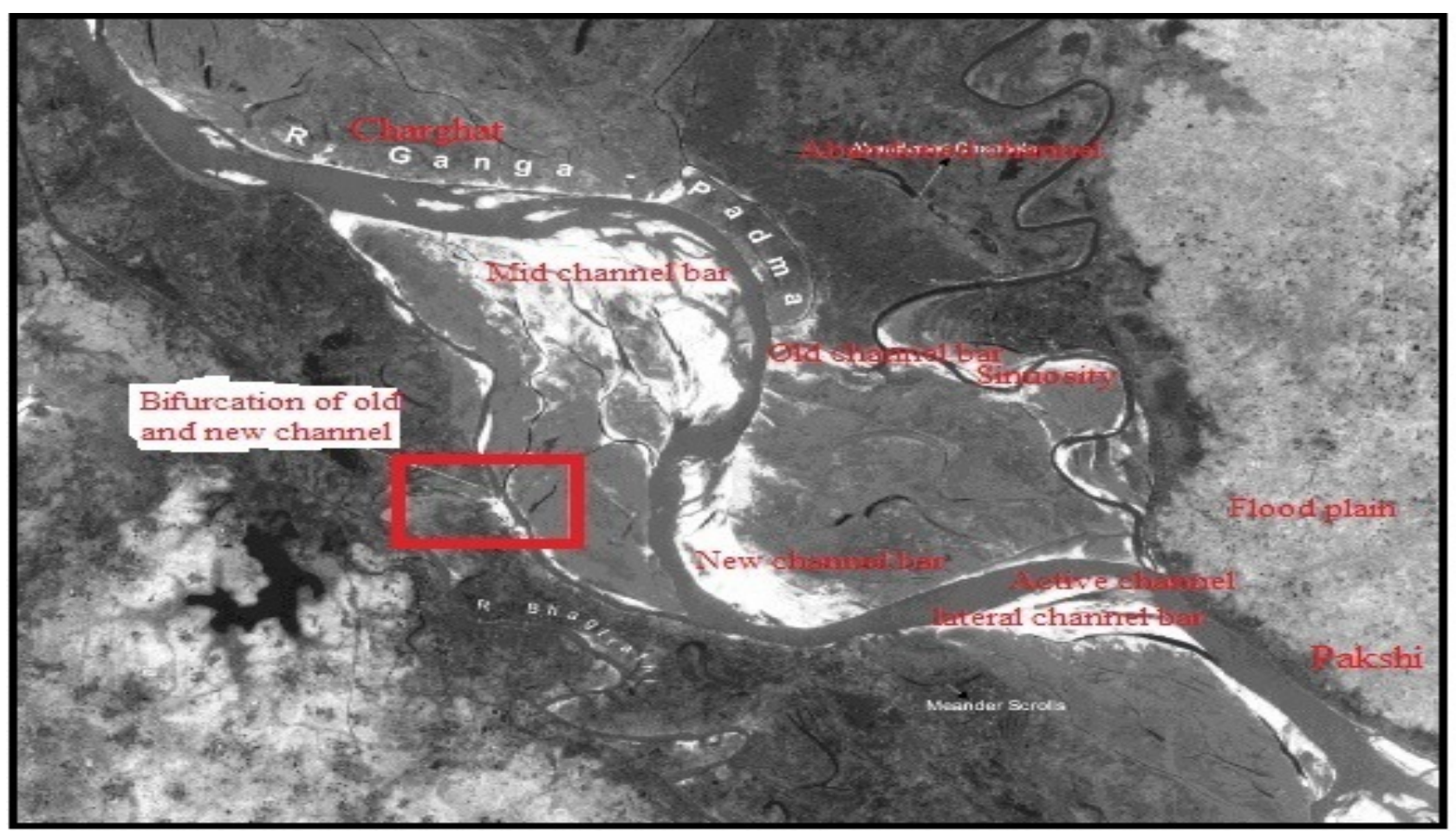

Figure 2. Fluvial morphological channel features of the study area using satellite images (After modified from [34])

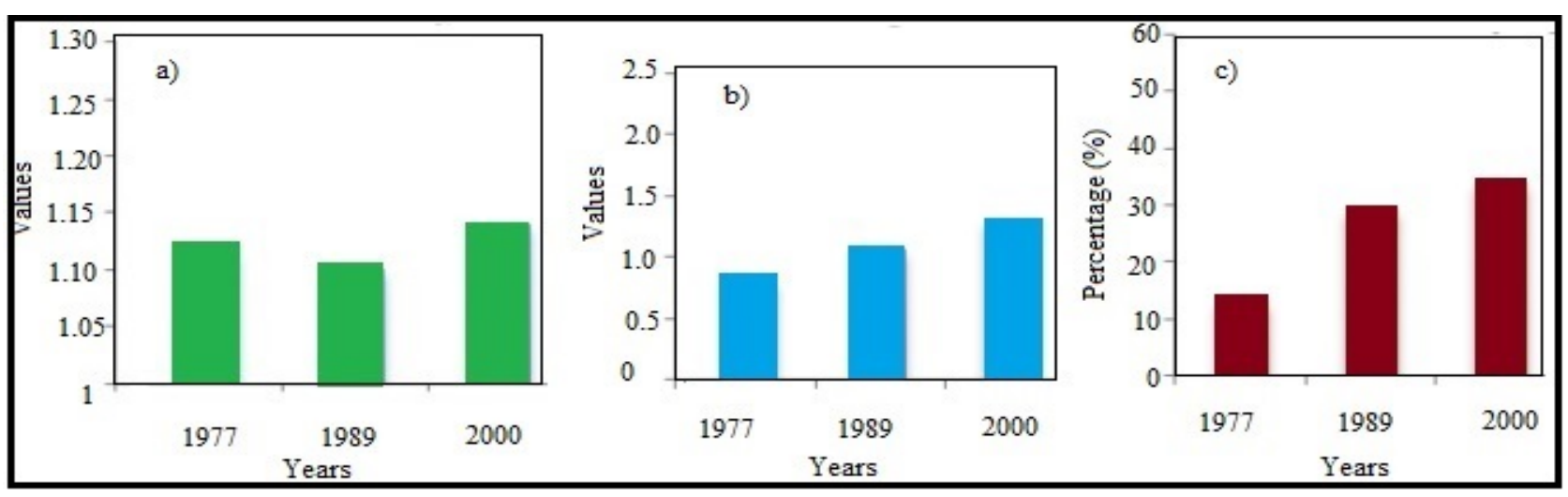

Figure 3. Sinuosity ratio, braided index and island area percentage of the study area

\section{Results and Discussion}

\subsection{Changes Detection over Time}

The Landsat satellite images were used to show the changes of the Padma River channel dynamics over the three decades. The sinuosity ratio (SR) was $1.13,1.12$ and 1.15 respectively (Fig. 3a). It indicates that the Padma River became more sinuous character over time. The braided index (BI) was about $0.83,1.10$ and 1.32 respectively with the increasing trend of river (Fig 3b). It signifies that the Padma River becomes meander to semi braided river in nature. The island area was about $13 \%, 30 \%$, and $35 \%$ respectively of the total area of river. There was an extreme change in the island area, an increase of $12.17 \%, 19.20 \%$ and $5.10 \%$ island area with increasing the river breadth (Fig. 3c). It showed that the erosion of bank line was increased significantly and also changes of river channel dynamics
(Fig. 4). Channel area has been significantly changed for the rapid sedimentation in right (west) bank rather than left (east) bank due to sinuosity ratio increased in right channel. It reveals that the lateral erosion has been increased because of high rate of sedimentation over the 23 year time periods. The braiding index (BI) has been increased with the increasing islands. For increasing sinuosity, island area and also braided index imply that the Padma River has been submerging the large areas of right (west) bank in almost every year. The comparison between sinuosity ratio and braiding index, it demonstrates that the changing rate of braiding index (BI) is more than the sinuosity ratio (SR). The changes in channel dynamics indicate that river needs to monitor for temporal shifting in each year. The results are consistent with analysis of the changing morphometry and shift bank line of the Ganges River using the space borne techniques which made by Laha and Bandyapadhyay [35]. 


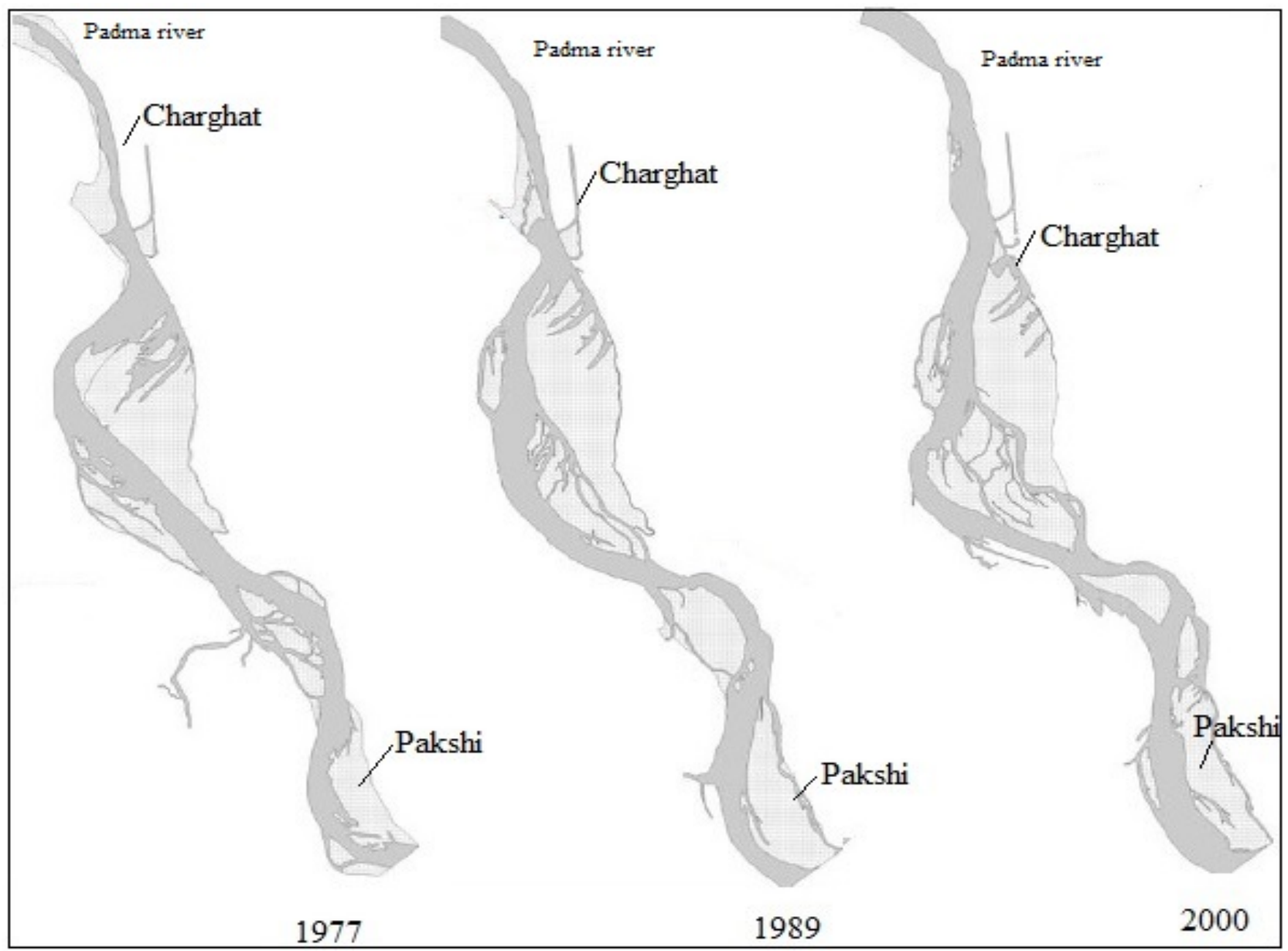

Figure 4. Detection of channel dynamic of the Padma River over the time using satellite images
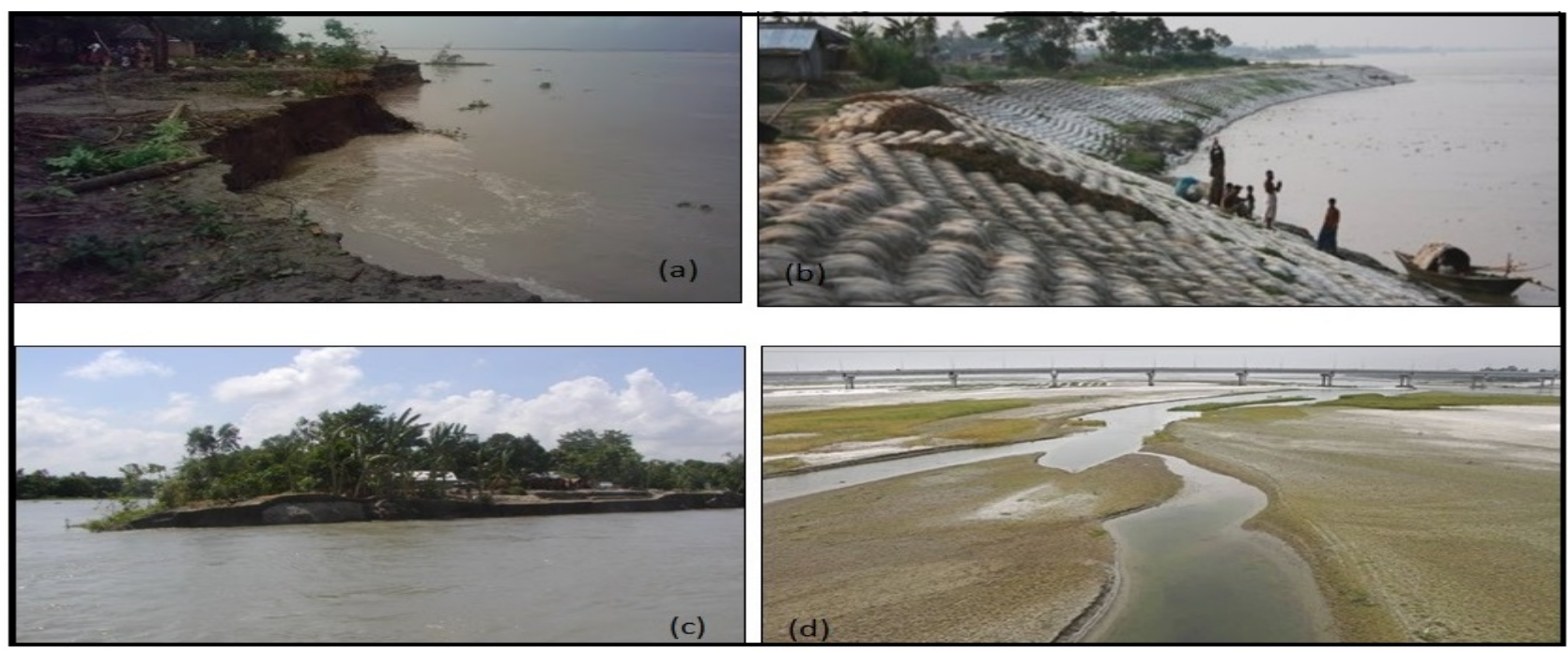

Figure 5. Photographs show river bank erosion of the study area; (a) bank erosion in Charghat area of Rajshahi district, northwestern Bangladesh; (b) River bank protection in Ramkrishnapur area of Rajshahi district in northwestern Bangladesh; (c) Char erosion in Pakuria area of Rajshahi district; (d) Char bar deposition in Sara area of Pubna district, northwestern Bangladesh

\subsection{River Bank Erosion}

River bank erosion is a complex fluvial process which depends on several factors. Among them, the most important factors are flood, irregular water flow and earthquake [36].
From the analyses of three satellite images of MSS 1977, TM 1989 and ETM+2000, it can be said that the river bank has been eroded and channel moves at different directions in different times within several locations. First, the area is located near Charghat union of Charghat area in the right 
bank of the Padma River (Site-A). Erosion was occurred towards western side during the last 23 years according to observation of satellite images (Fig. 5a). Second, the area is migrated in the right bank near Ramkrishnapur union of Bagha area of Rajshahi district of the Padma River (Site-B). From satellite image of 1977 to 2000, it showed a remarkable change of the river bank line (Fig. 5b). Third, it is placed in Marich union of Bagha area of Rajshahi district at right bank of the river. The rate of erosion was occurred during the time period of 1977 to 1989 , probably at the same points in this site-C. Fourth, Bahadurpur and adjacent areas are included at right bank of the river (Site-D). Fifth, this site-E is covered in Pakshi area at the right bank of the Padma River. Sixth, site-F is situated in Pakuria Union of Bagha and adjacent areas at left bank of the river. From time period of 1977 to 1989, erosion was occurred at slower rate than before but after 1989, it was observed a remarkable change of the bank line toward west direction (Fig. 5c). Seventh, site-G is located in Sara Union and adjoining areas at left bank of the river. The overall rate of erosion was much higher in 1989-2000 than 1977-1989 time periods and the river width increased with increasing rate of erosion in site-G (Fig. 5d).

\subsection{Channel Shifting}

Quantitative analyses of the positions of channel shifting demonstrate that westward migration has occurred in the Padma River (Table 2). This is due to right bank (west) between 1977 and 2000 has not balanced by left bank (east) between 1977 and 2000. The changes in trend line can be ascribed mostly due to a switch in the direction of the right (west) bank migration: before 1977, this was advancing eastwards direction at a slower rate than the east (left) bank was retreating to produce eastward movement and narrowing the channel. Conversely, since 1977, the west (right) bank has been retreating at a higher rate than that of the east (left) bank, producing westward movement and accelerated widening channel continue in recent decades. The findings show that the river moves from the east to westward. Because of its topography is complex displaying morphological features that may be ascribed to neo-tectonics, fluvial processes and sedimentation associated with right (west) bank distributaries. So, the future study requires for predicting precisely morphological changes and its trend line position in the Padma River.

Table 2. The westward shifting of the channel of the Padma River

\begin{tabular}{|c|c|c|c|}
\hline Duration & $\begin{array}{c}\text { Right bank } \\
\text { (west) }\end{array}$ & $\begin{array}{c}\text { Left bank } \\
\text { (east) }\end{array}$ & Central line \\
\hline Since 1977 & $2-3$ & -2 & -0.5 \\
\hline $1977-1989$ & 3 & 1 & 1 \\
\hline $1989-2000$ & 6 & -1 & -1 \\
\hline
\end{tabular}

N.B: Data are in kilometers and a minus sign denotes eastward shifting

The channel shifting of the Padma River obtained during the time periods of 1977 to 2000 (23 years) and the superimposed bank line maps are presented in Fig. 6. During 1977 s the bank line movement was relatively slow. In order to get clear picture and to compare the changes of bank line of Padma River using the GIS superimposed have shown on the 1977-1989 and 1989-2000 of satellite images, different rates of bank erosion were detected in the time periods from 1977 to 2000. The bank line shifting was identified significantly at the upstream side which occurred in westward direction of the Padma river whereas minor eastward shifting of bank line was observed in the lower part of the Pakshi area in northwestern Bangladesh (Fig. 6). From the overall observation of channel shifting indicates that the channel shifting at upper middle part of Padma River (Rajshahi district) showed westward shifting of bank line while the lower part (Pabna district) of the river shifted in eastward direction from 1977 to 2000 time periods. The width of the Padma River almost double in (1989-2000) compared to (1977-1989). From the satellite images, it shows that the overall width of the Padma River has increased from around $4 \mathrm{~km}$ to $6 \mathrm{~km}$ during the last 23 years. Mid channel bar like Gargari is eroded mostly and shifted its original position. The bank migration was prominent in those areas. The previous results of Talukder and Islam [39], Samsuzzaman et al. [37] and Uddin [38] supported this finding. From the above discussion, it is clear that the bank of the Padma River is very much unstable in nature and changes its banks often frequently. 


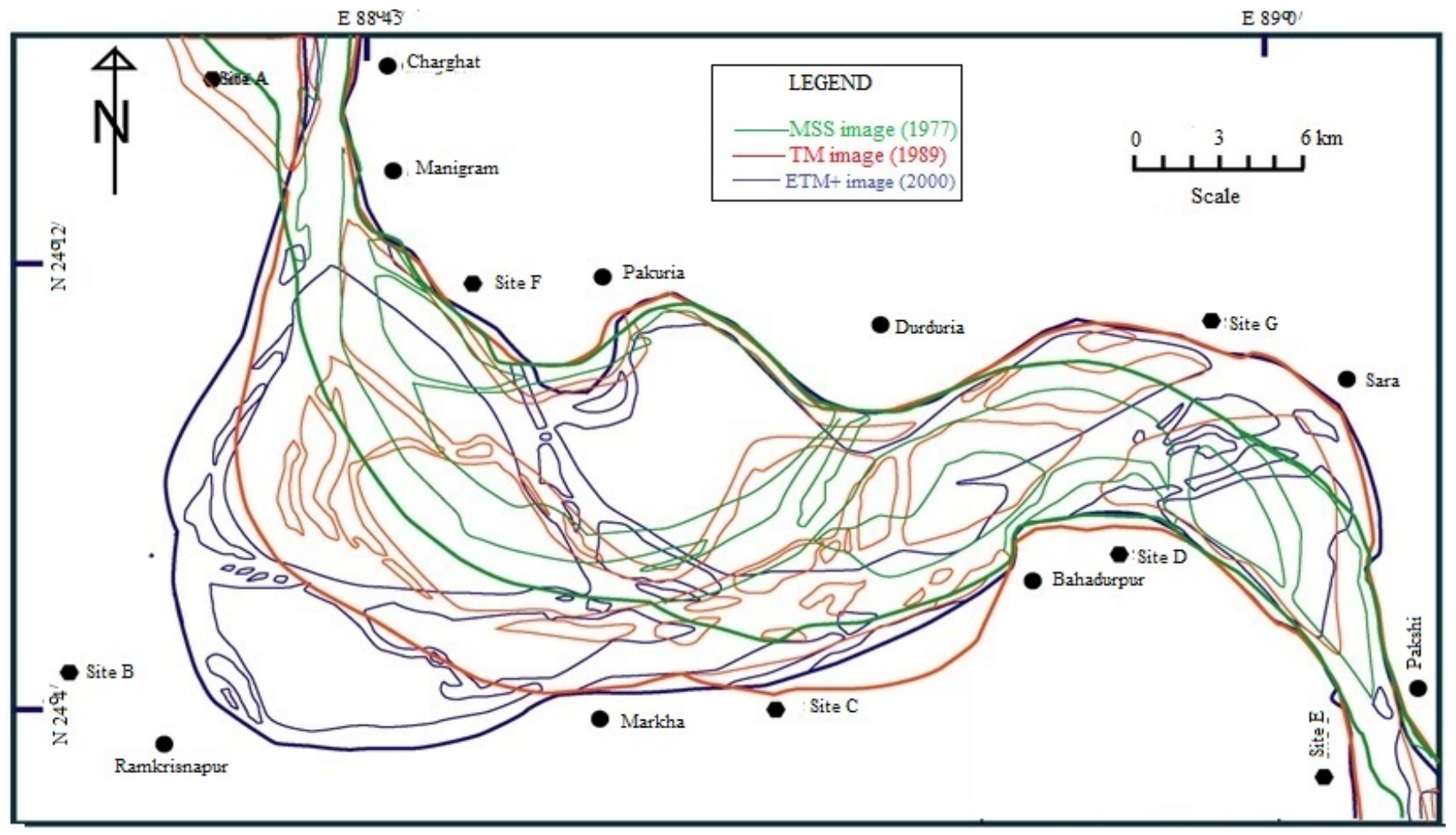

Figure 6. Geomorphological map and its superimposed bank lines of Landsat MSS 1977, TM 1989 and ETM+ 2000

\section{Conclusions}

The Padma River provides an important site for fundamental research on channel dynamics in complex fluvial geomorphology. This study aims to explore the change of fluvial channel dynamics and shifting of channel of the Padma River in surrounding area. The Padma is a typical meandering river with highly dynamics in nature. Results indicate that the morphological change is comparatively high because of alteration of the fluvial flow regime in the study area. The satellite images show that sinuosity ratio, braided index and island area in right bank of the river channel are increased due to high rate of sedimentation. In the last 23 years, the Padma River has shifted dramatically from east to west, greatly near Ramkrishnapur and Sara Union of Rajshahi district, northwestern Bangladesh. Results also demonstrate that the maximum amount of channel shifting was about $6 \mathrm{~km}$ near Ramkrishnapur and about $3 \mathrm{~km}$ at Maricha Union of Rajshahi district at right (west) bank side. This situation is alarming due to bank erosion in the right (west) bank rather than left (east) bank of the river from Charghat to Pakshi area of northwestern Bangladesh in the last several decades. The fluvio-morphological changes have established in this study that differ from the right (west) to left (east) banks caused by previous eastward migration of the Padma River result in opposing patterns of behavior along the west side of the river. Such knowledge will be helpful in evaluating the fluvio-morphological change and for planning outlines to develop the protective measure in the study area.

The following recommendation should be required in the study area for future river bank protection:

i) River bank protection and upstream water flow control should be established considering the geomorphological and geological mapping in northwestern Bangladesh.

ii) Geographic and geologic information are essential at primary stages for preparing geomorphological and land use mapping in order to reduce hazardous effect in the study area.

iii) Rehabilitation should be initiated by the government over long run to minimize the effects of flood affected people of the Padma River bank side areas.

iv) This research has some limitation due to limited field survey and 15 year old data used. So, there is a requirement of further studies to evaluate precisely the channel patterns and morpho-dynamics of the Padma River using the digital elevation model (DEM) in the study area.

\section{REFERENCES}

[1] Islam SN, Singh S, Shaheed H and Wei S. Settlement relocations in the char-lands of Padma River basin in Ganges delta, Bangladesh, Frontiers of Earth Science in China, 2010; 4(4):383-402

[2] Petts GE. Changing river channels: the geographical tradition. In: Gurnell, A.M., Petts, G.E. (Eds.), Changing River Channels. John Wiley and Sons, Chichester, pp. 1-23, 1995. 
[3] Alam MM. Parallel lamination in sandy deposits of the Jamuna River, Bangladesh. Significance in paleofluvial interpretation; Bangladesh Geoscience Journal, 1996; 2: $37-46$.

[4] Hassan S and Akhtaruzzaman AFM. Environmental Change Detection of the Padma river in the North-Western part of Bangladesh using Multi-date Landsat Data, Proc. of International Conference on Environmental Aspects of Bangladesh (ICEAB10), Japan, Sept. 2010.

[5] Neill CR, Oberhagemann K, McLean D and Ferdous QM. River training works for Padma multipurpose bridge, Bangladesh, River training and control - the guide bank system. Railway Board, New Delhi, India, 2010.

[6] Thorne CR, Russell PG, Alam MK. Planform pattern and channel evolution of the Brahmaputra River, Bangladesh. In: Best, J.L., Bristow, C.S. (Eds.), Braided Rivers, vol. 75. Geological Society of London, Special Publication, pp. 257$276,1993$.

[7] Yang X, Damen MCJ, Van Zuidam RA. Satellite remote sensing and GIS for the analysis of channel migration changes in the active Yellow River Delta, China. International Journal of Applied Earth Observation and Geoinformation 1:146-157, 1999.

[8] Leigh DS, Srivastava P, Brook G.A. Late Pleistocene braided rivers of the Atlantic coastal plain, USA. Quaternary Science Reviews 23, 65-84, 2004.

[9] Baki ABM, Gan TW. Riverbank migration and island dynamics of the braided Jamuna River of the Gangese Brahmaputra basin using multi-temporal Landsat images, Quaternary International, 2012; 263: 148-161.

[10] Downward SR, Gurnell AM, Brookses A. A Methodology for Quantifying River Planform Change Using GIS. In: Variability in Stream Erosion and Sediment Transport, L.J. Oliva, R.J. Lorghran, and J.A. Kesby (Editors). International Association of Hydrological Sciences Publication 224: Wallingford, UK, pp.449-456, 1994

[11] Marston RA, Girel G, Pautou G, Piegay H, Bravard J, Arneson C. Channel metamorphosis, floodplain disturbance, and vegetation development: Ain River France. Geomorphology, 1995; 13:121-131

[12] Gurnell AM. Channel change on the River Dee meanders, 1946-1992, from the analysis of air photographs. Reg Rivers Res Manag, 1997; 13:13-26

[13] Islam ARMT, Sein ZMM, Ongoma V, Islam SM, Alam MF, Ahmed F. Geomorphological and Land Use Mapping: A Case Study of Ishwardi Under Pabna District, Bangladesh, Advances in Research 4(6): 378-387, 2015. doi: 10.9734/AIR/2015/14149.

[14] Khan MSS, Islam ARMT. Anthropogenic Impact on Morphology of Teesta River in Northern Bangladesh: An Exploratory Study, Journal of Geosciences and Geomatics, 2015, 3 (3):50-55. doi: 10.12691/jgg-3-3-1.

[15] Islam S, Islam ARMT, Rahman F, Ahmed F and Haque MN. Geomorphology \& Land use mapping of Rangpur District, Bangladesh, Journal of Geosciences and Geomantic, 2014; 2(4):145-150. DOI: 10.12691/jgg-2-4-2.

[16] Takagi T, Oguchi T, Matsumoto J, Grossma MJ, Sarker MH, Matin MA. Channel braiding and stability of the Brahmaputra
River, Bangladesh, since 1967: GIS and remote sensing analyses. Geomorphology, 2007; 85:294-305

[17] Mount NJ, Tate NJ, Sarker MH, Thorne CR. Evolutionary, multiscale analysis of river bank line retreat using continuous wavelet transforms: Jamuna River, Bangladesh. Geomorphology, 2013; 183:82-95.

[18] Akhtar MP, Sharma N, OJHA CSP. Braiding process and bank erosion in the Brahmaputra River. Int J Sed Res , 2011; 26:431-444

[19] Sarker MH, Thorne CR, Aktar MN, Ferdous MR. Morphodynamics of the Brahmaputra-Jamuna River, Bangladesh. Geomorphology, 2014; 215:45-59

[20] Bhuiyan MAH, Kumamoto T \& Suzuki S. Application of remote sensing and GIS for evaluation of the recent morphological characteristics of the lower Brahmaputra-Jam una River, Bangladesh, Earth Sci. Inform, 2014 (In press). DOI 10.1007/s12145-014-0180-4.

[21] CEGIS. Identification of the different types of bank materials along the Padma River-Morphologic Study Applying Remote Sensing for the feasibility Study of Padma Bridge, Prepared for JICA Study Team in Bangladesh for the Feasibility Study of Padma Bridge, Dhaka, Bangladesh, pp.28, 2004.

[22] CEGIS. Developing empirical methods for predicting morphological changes in the Padma River, Prepared for Jamuna-Meghna River Erosion Mitigation Project, BWDB, Dhaka, Bangladesh, pp. 48, 2005a.

[23] CEGIS. Prediction of Bank Erosion and Morphological Changes of the Jamuna and Padma Rivers 2005, Prepared for EMIN and JMREM Projects, Dhaka, Bangladesh, pp. 125, 2005b.

[24] McLean DG, Vasquez JA, Oberhagemann K and Sarker MH. Padma River morphodynamics near Padma Bridge, River Flow 2012, Chapter.100, CRC Press, 2012; pp. 741-747.

[25] Khan FH. Geology of Bangladesh: University Press Limited, 207, 1991.

[26] CEGIS. Long-term erosion process of the Jamuna River. Centre for Environmental and Geographic Information Services, Dhaka. 74 pp, 2007.

[27] Barker R, Dixon L, Hooke J. Use of terrestrial photogrammetry for monitoring and measuring bank erosion. Earth Surf Process Landforms, 1997; 22:1217-1227.

[28] Lillesand TM and Kiefer RW. Remote Sensing and Image Interpretation (Second ed.): Willey and sons. Inc., 1987; 721.

[29] Yokoyama R, Shirasawa M and Pike RJ. Visualizing topography by openness: a new application of image processing to digital elevation models, Photogrammetric Engineering and Remote Sensing, 2002; 68:257-265.

[30] Reddy GBO and Maji AK. Delineation and characterization of geomorphological features in a part of lower maharahstra metamorphic plateau using IRS-ID LISS-III Data, Journal of the Indian Society of Remote Sensing, 2003; 31(4):241-250.

[31] Roy MK and Islam MS. Morphological and architectural elements of the Padma River near Bagha, Rajshahi, Bangladesh. Rajshahi University Studies, Part B, Journal of Science, 2005; 33:115-128.

[32] Dunbar CO and Rodgers J. Principles of Stratigraphy. Wiley 
International Edition. Tokyo, Japan, 1957; 271-288.

[33] Gupta N. Channel planform dynamics of the Ganga-Padma system, India, PhD thesis, University of Southampton, UK, pp.51, 2012. http://eprints.soton.ac.uk.

[34] Haq E, Islam MB, Ahmed SS and Islam MS. Lithofacies of the Padma River near Rajshahi City, Bangladesh. Bangladesh Journal of Geology, 2000; 17:11-22.

[35] Laha C, Bandyapadhyay S. Analysis of the changing morphometry of river Ganga, shift monitoring and vulnerability analysis using space-Borne techniques: A statistical approach, Intern. J. of Scie. and Res. Pub., 2013; 3(7): $1-10$.
[36] Alam AKM. Neotectonic evidence along the Eastern margin of the Barind Tract, Bangladesh: Bangladesh Journal of Geology, 1995; 14:25-31.

[37] Shamsuzzaman M, Islam MS and Islam MB. Morphogeology of Pabna Sadar Upazila, Bangladesh. Bangladesh Journal of Water Resource Research, BUET, 2005; 20: 65-79.

[38] Uddin AFMK. Changing river courses in Bangladesh: A Historical appraisal, journal of the Bangladesh National Geographical Association, 1973; (2): 6-12.

[39] Talukder S and Islam MS. Morphogeology of Natore Town and adjacent areas, Bangladesh. Rajshahi University Studies, Journal of Science, 2006; 34 (part B):211-222. 